\title{
Dziecko w pogoni za szczęściem. Pozory szczęśliwego dzieciństwa
}

\section{KEYWORDS}

childhood, happiness, children's life in the 21 st century, images of childhood, lifestyles of contemporary family

\begin{abstract}
Kuszak Kinga, Dziecko w pogoni za szczęściem. Pozory szczęśliwego dzieciństwa [Children in search of happiness. Appearances of a happy childhood]. Kultura Społeczeństwo - Edukacja nr 1(13) 2018, Poznań 2018, pp. 31-47, Adam Mickiewicz University Press. ISSN 2300-0422. DOI 10.14746/kse.2018.13.2.
\end{abstract}

The article tackles the issue of the contemporary childhood. The author notes that in search of a happy childhood, the essence of childhood is often lost. Instead of a genuinely careless and happy childhood, the reality created for today's children is full of appearances. In her discussion of the subject, the author refers to a selected approach to happiness. She also identifies, based on Janusz Czapiński's proposal, the difference between happiness and feeling happy. She points to the fact that 21 st-century life is an endless chase after the future, lacking the opportunity to focus on here and now. Childhood too is treated as a race towards adulthood. In the course of her argument, the author identifies and describes selected styles of creating a happy childhood: an abundant childhood, an active childhood, a childhood in the limelight, a boundless childhood, a childhood among people. Concluding her argument, the author proposes that instead of chasing happiness and creating the appearances of a happy childhood for children, it might be better to simply slow down the pace of life when possible and value the present. After all, "sharing the joy of life is the essence of a satisfying child-parent relationship". The author also discusses the role of the teacher as a person supporting the parents in their parenting roles. 


\title{
Wprowadzenie
}

\author{
(...) żyjemy dłużej, \\ ale mniej dokładnie \\ i krótszymi zdaniami (...) \\ (...) Podróżujemy szybciej, częściej, dalej, \\ Choć zamiast wspomnień przywozimy slajdy (...) \\ Wisława Szymborska Nieczytanie
}

Podobnie jak wielu obserwatorów współczesnego życia, Wisława Szymborska dostrzega, że nieustanna zmiana, wynikający z niej brak czasu i pośpiech, konsumpcja, dążenie do łatwej i szybkiej rozrywki zdominowały dziś życie człowieka. Ceną, jaką za to płacimy, jest nieustanne ryzyko i nieprzewidywalność. Anthony Giddens podkreśla, że zdewaluowało się też pojęcie kontroli, bowiem „zmiany wykraczają poza wszelkie oczekiwania człowieka i wymykają się jego kontroli” (Giddens, za: Bogunia-Borowska, 2008: 67). Brak możliwości wpływania na przebieg zdarzeń zwiększa poczucie niepewności. Bogunia-Borowska podaje za Urlichem Beckem, iż ryzyko, jakie ponosi współczesny człowiek, wynika z jednej strony $\mathrm{z}$ tego, że każda jednostka zachęcana jest do samodzielności i daleko posuniętej indywidualizacji, $\mathrm{z}$ drugiej zaś jest ograniczona w procesie indywidualnego działania. Jego zdaniem

w zaawansowanej nowoczesności indywidualizacja realizuje się w ramowych warunkach takiego procesu uspołecznienia, który w coraz większym stopniu uniemożliwia usamodzielnienie się: jednostka jest wprawdzie uwolniona od tradycyjnych więzi i źródeł zabezpieczania bytu, musi za to wypełnić nakazy rynku pracy i wieść egzystencję konsumenta, podlegając odnośnym standaryzacjom i mechanizmom kontroli (...) występują wtórne instancje i instytucje, które wpływają na życiorys jednostki i czynią z niego, wbrew indywidualnej dyspozycji (...) igraszkę mód, koniunktur i rynków. (Bogunia-Borowska, 2008: 69)

W takiej rzeczywistości zmienił się też model funkcjonowania dziecka i obraz szczęśliwego dzieciństwa.

\section{Wybrane ujęcia szczęścia}

Szczęście od początków myśli ludzkiej uważane jest za jeden z ideałów życiowych, zaś poszukiwanie jego istoty odnaleźć można w pracach filozofów od czasów starożytnych. Analizując bogatą literaturę dotyczącą tego zagadnienia oraz odwołując do wiedzy potocznej, można stwierdzić za Januszem Czapińskim: 
o szczęściu powiedzieć można to samo, co św. Augustyn napisał na temat czasu: „wszyscy wiedzą doskonale, czym jest, dopóki ktoś nie zapyta o definicję”. Pojęcie szczęście podobne jest do takich pojęć jak: sztuka, język, gra, nauka. Nie da się go zdefiniować w klasyczny sposób, bowiem (...) zawiera w sobie całą rodzinę znaczeń pozbawioną jednego wspólnego elementu wyróżniającego. (Czapiński, 1994: 6)

Niezależnie od obiektywnych trudności wyrażenia słowami tego, co kryje się pod pojęciem „szczęście”, ludzie podejmują starania, by, jak stwierdził Wilhelm von Humboldt, dokonać refleksji, wstrzymać umysłem „na chwilę postępy swego działania, a następnie to, co właśnie sobie przedstawił, ująć w jedność i w ten sposób przeciwstawić samemu sobie jako przedmiot" (Humboldt, 2012: 152). Ludzki wysiłek, by zdefiniować szczęście, wymaga zrozumienia, że różne treści pod nie podkładane „mają własny wymiar historyczny, występują w otoczeniu sobie właściwych realiów i dlatego nie dają się przenieść w sposób wierny w inne, odległe czasy" (Głombik, 1982: 11).

Zdaniem Władysława Tatarkiewicza istnieją cztery zasadnicze ujęcia:

1) szczęście jako pomyślny los, inaczej rzecz ujmując - pomyślny układ zdarzeń, szczęśliwy traf;

2) szczęście jako intensywna radość, stan błogości lub upojenia;

3) szczęście jako posiadanie najwyższych dóbr;

4) szczęście jako zadowolenie z życia. (Tatarkiewicz, 1947: 17)

Autor podkreśla, że

ta poczwórność jest obfitym źródłem mętności w naszych myślach o szczęściu, cztery bowiem pojęcia oznaczane jednym mianem mają tendencję do przenikania się wzajem w świadomości i wytwarzania jednego pojęcia o treści nieokreślonej (...). I choćby filozofowie przyjęli tylko jedno $\mathrm{z}$ nich, a wyeliminowali pozostałe, to przeciętny człowiek zachowa skłonność do nazywania jednym wyrazem tych czterech różnych rzeczy. (Tatarkiewicz, 1992: 131)

Zauważa następnie, że całkowitego, zupełnego i stałego szczęścia człowiek nie osiąga właściwie nigdy. W związku z tym zawsze należy odróżnić ideał życia szczęśliwego [teoretycznej koncepcji szczęścia - dop. K.K.] od realnego poczucia szczęścia, jakiego doświadcza, czy może doświadczyć każda jednostka. Tatarkiewicz dostrzega, że człowiek nie jest zdolny przeżywać szczęścia bez przerwy, gdyż „nie może nieustannie myśleć o swym życiu” (Tatarkiewicz, 1947: 25). Nie jest też możliwe ciągle przeżywanie przyjemności, gdyż „przyjemność, która trwa, staje się przykrością” (Tatarkiewicz, 1947: 26). Proponuje więc następującą definicję szczęścia: „szczęście jest trwałe, pełne i uzasadnione zadowolenie z życia” (Tatarkiewicz, 1947: 32), „uzasadnione” to znaczy nie oparte na iluzji, lecz realne. 
James R. Averill i Thomas A. More (2005: 832), analizując istotę szczęścia, opisują je w czterech pojęciach, co przedstawia tabela $\mathrm{nr} 1$.

Tabela 1. Cztery pojęcia szczęścia

\begin{tabular}{|l|l|l|}
\hline \multicolumn{2}{|c|}{ Stopień obiektywności } \\
\hline Poziom aktywacji & Subiektywny (dobre samopoczucie) & Obiektywny (właściwe postępowanie) \\
\hline Wysoki & Radość & Eudajmonia \\
\hline Niski & Zadowolenie & Spokój ducha \\
\hline
\end{tabular}

Źródło: J.R. Averill, J.R. More, 2005: 832

Pierwszy wymiar obejmuje doznania i sytuuje się na kontinuum od stanów niskiej aktywności - zadowolenie, równowaga psychiczna, spokój ducha - do stanów wysokiej aktywności, jak radość, podniecenie, ekstaza. Zaś drugi wymiar, czyli stopień obiektywności, łączy się z ustaleniem stanu emocjonalnego na podstawie kryteriów wewnętrznych (subiektywnych) lub zewnętrznych (obiektywnych). Warto podkreślić, co czynią autorzy, że „chociaż zadowolenie i radość różnią się poziomem aktywacji, obie te emocje mają nieuchronny komponent subiektywny" (Averill, More, 2005: 832). Zdaniem J.R. Averill i J.R. More szczęście należy utożsamiać $\mathrm{z}$ eudajmonią, jest więc stanem krótkotrwałym i przejawia się określonym rodzajem zachowania. Dotyczy ono zaangażowania w działania mające dla danego człowieka duże znaczenie, nawet jeśli trzeba w trakcie ich realizacji znosić chwilowe niewygody i pokonywać trudności (Averill, More, 2005: 833). Można więc powiedzieć, że szczęście jest dążeniem ku czemuś istotnemu, subiektywnie lub obiektywnie wartościowemu. Tym tropem zmierza też Maria Szyszkowska, podkreślając:

dążenie do urzeczywistnienia wyższych wartości, niesłabnąca i ukierunkowana (...) energia człowieka, radość walki i zmierzanie do nieosiągalnego w pełnym wymiarze celu - oto w czym przede wszystkim wyraża się człowieczeństwa. Na tej drodze doznawać możemy przeżycia szczęścia, które wzmaga naszą wolę wytrwania w obranym kierunku niezależnie od wszelkich przeciwności. (Szyszkowska, 1985: 384)

Jak zaznacza autorka, warunkiem osiągnięcia poczucia szczęścia jest z jednej strony jego oczekiwanie, z drugiej strony cel działań (Szyszkowska, 1985: 385). Jest to możliwe tylko wówczas, gdy jednostka potrafi znaleźć oparcie w samej sobie. M. Szyszkowska zauważa też:

trwałe szczęście wiąże się z trudną drogą rozwoju wewnętrznego łączącego się ściśle ze zmierzaniem ku wartościom przekraczającym aktualny wymiar istnienia. Dążąc do celów utylitarnie pożytecznych, przeżywa się najwyżej przyjemność, nigdy szczęście (...). Szczęście splata się z działaniem z pozytywną mobilizacją ku urzeczywistnieniu wartości. (Szyszkowska, 1985: 393) 
Co ważne, „doznawać szczęścia można wtedy, gdy odrzuca się świat utrwalony w pojęciach, gdyż dochodzi się do uchwycenia tego, co dynamiczne w rzeczywistości nas otaczającej (...). Szczęście jest przeżyciem, toteż zamiera, gdy zostaje ubrane w słowo" (Szyszkowska, 1985: 395). Inni autorzy: Sonja Lytubomirsky, Ken Sheldon i David Schakade nie tylko podjęli próbę „ubrania w słowa” tego, co zawiera się w pojęciu „szczęście”, zaproponowali też następującą formułę (happiness formula):

$$
\mathrm{S}=\mathrm{U}+\mathrm{O}+\mathrm{W}
$$

Poziom doświadczanego przez człowieka szczęścia (S) jest, ich zdaniem, zdeterminowany przez uwarunkowany biologicznie potencjalny zakres poczucia szczęścia (U) oraz okoliczności życiowe (O) i czynności wolicjonalne (W) (Haidit, 2007: 168). Przy czym „W” to, jak podkreśla J. Haidit, świadome, zamierzone działania, które kształtują w nas postawę akceptacji i osłabiają emocjonalne przywiązanie do świata zewnętrznego (Haidit, 2007: 169).

Istotnym elementem szczęścia jest wewnętrzna motywacja do bycia szczęśliwym. Zdaniem Janusza Czapińskiego istnieją trzy wymiary szczęścia, do których można zaliczyć:

- wolę życia,

- ogólny dobrostan psychiczny,

- satysfakcje cząstkowe. (Czapiński, 1994: 14nn)

Autor dokonuje rozróżnienia dwóch pojęć: „szczęścia” i „poczucia szczęścia”. Jego zdaniem to pierwsze jest "pozytywną postawą wobec celów, z którymi człowiek się utożsamia, które nadają sens jego życiu” (Czapiński, 1994: 144), zaś poczucia szczęścia doświadczają ci, którzy „mają charakter świadomej oceny własnego życia. Doznania te i sądy mogą znacznie łatwiej zmieniać się pod wpływem różnorodnych okoliczności życia niż rdzeń szczęścia” (Czapiński, 1994: 144).

$\mathrm{Z}$ tych wybranych dla potrzeb niniejszego opracowania definicji i ujęć wynika, że szczęście jest związane $\mathrm{z}$ wewnętrznym poczuciem dobrostanu, będącym rezultatem możliwości, jakie ma jednostka, by realizować realne, osobiste (nienarzucone z zewnątrz) cele wynikające z uznanych wartości. Przyjmując za punkt wyjścia takie ujęcie, w dalszej części opracowania podejmę próbę analizy funkcjonujących w świadomości społecznej (niejednokrotnie kreowanych czy inspirowanych przez przekazy medialne) obrazów szczęśliwego dzieciństwa.

\section{Wzory czy pozory szczęśliwego dzieciństwa?}

W obecnym dyskursie na temat dzieciństwa podkreśla się, że dziecko „jest opisywane jako podmiot rozwoju zakorzeniony w kulturze i historii (...). Przyjmuje się, 
że dzieciństwo jest społecznie konstruowane, a więc nie jest naturalnie dane, lecz zostaje ukształtowane $\mathrm{w}$ istotnych sprawach przez kontekst historyczny $\mathrm{i}$ kulturowy" (Matjas, 2008: 36). Obserwując rzeczywistość, w której funkcjonują współczesne dzieci, nie można się też nie przychylić do spostrzeżenia Danuty Waloszek, że współczesnym dzieciństwem „manipuluje się na niespotykaną dotąd skalę. Wszystko dla reklamy, dla zysku, dla popularności. Najbardziej niebezpieczne są postawy wielu rodziców i pedagogów, którzy na taką manipulację się zgadzają" (Waloszek, 2006). Dzieciństwo traktowane jest jako etap życia, w którym człowiek staje się; dopiero w przyszłości będzie wartościowym członkiem społeczeństwa, można więc ingerować w jego przebieg. W świadomości społecznej funkcjonuje przekonanie, że młody człowiek rozwija się, „a zatem z jednostki niedoskonałej, niekompletnej, za pomocą różnych czynników (...) staje się coraz «dojrzalszy» i «bardziej rozwinięty»" (Maciejewska-Mroczek, 2012: 56). Dzieciństwo jest więc punktem wyjścia do lepszego (czasem gorszego) życia w dorosłości. Postrzegane jako etap, w którym podejmuje się inwestycję w późniejsze życie jednostek. Konsekwencją tego jest „przyspieszanie” dzieciństwa i skracanie okresu bycia dzieckiem lub wręcz zastępowanie dzieciństwa szybką dorosłością, co przejawia się na przykład w sferze zachowania się, ubioru, desygnatów typowych kiedyś dla starszej grupy wiekowej (Postman, 1982: 125nn), seksualności, swobody obyczajowej (Gajda, 2009: 25), dostępu do patologii, narkomanii, przemocy, bandytyzmu (Adamski, 1999). Jak podkreśla Jacek Z. Górnikiewicz „małoletni w szybkim tempie wnikają w rzeczywistość do niedawna zawarowaną dla dorosłych, a cały ten proces jest silnie katalizowany przez przemożne nowe media, zwłaszcza Internet" (Górnikiewicz, 2010: 143). Dzieciństwo ma przecież stanowić dobrą trampolinę do szczęśliwego życia w dorosłości. Aby tak się stało, musi być „czasem szczególnej pracy nad sobą i na rzecz lat przyszłej kariery/stabilizacji” (Górnikiewicz, 2010: 143). Żyjemy bowiem w kulturze ,jednego tylko czasu” - czasu przyszłego, „czas przeszły traktuje się jako miejsce godnych pogardy przeżytków, a czas teraźniejszy jako punkt wyjścia do przyszłości” (Łukaszewski, 1996: 233). Dodatkowo eksponuje się rolę szczęśliwego dzieciństwa. Nie sposób nie zgodzić z Heleną Izdebską, która zauważa, że „dążenie do zapewnienia dzieciom szczęścia urasta $\mathrm{w}$ wielu rodzinach [także w mediach - dop. K.K.] do rangi spraw najważniejszych, a przy bardzo dowolnej interpretacji tego, co miałoby ono oznaczać, daje na ogół rezultaty negatywne i wbrew pragnieniom zubaża proces wychowania" (Izdebska, 1988: 9). Żyjemy w czasach przymusu bycia szczęśliwym i przymusu szczęśliwego dzieciństwa. Dokonam zatem analizy pięciu wyodrębnionych dla potrzeb tego opracowania pozorów szczęśliwego dzieciństwa, które wyłaniają się z badania stylów życia dzieci i ich rodziców: 
- dzieciństwa obfitego ${ }^{1}$,

- dzieciństwa aktywnego,

- dzieciństwa w świetle reflektorów,

- dzieciństwa nieskrępowanego,

- dzieciństwa między ludźmi.

\section{Dzieciństwo obfite}

Robert Frank zauważył, że współcześni ludzie tracą wiele cennej energii na dążenie do celów, które tylko z pozoru przynoszą szczęście (Frank, 1999). Do nich należy zapewnienie obfitości dóbr materialnych, co oczywiście wiąże się z nieustanną konsumpcją. Tezę tę rozwija Zygmunt Bauman, podkreślając, że ludzie, którzy praktykują konsumpcyjną [obfitą - dop. K.K] formę życia, tęsknią przede wszystkim za zawłaszczeniem, posiadaniem i gromadzeniem przedmiotów cenionych za wygodę i/lub szacunek społeczny, którymi mają obdarzyć właścicieli (Bauman, 2009: 36-37). Jak pisze dalej wspomniany autor, konsumpcjonizm wiąże wizję szczęścia nie tyle z zaspokojeniem potrzeb, ile z ciągle rosnącą liczbą i nasilaniem się pragnień wymagających natychmiastowego spożycia i śpiesznego zastąpienia przedmiotów, które mają te pragnienia zaspokajać (Bauman, 2009: 39). Mamy więc do czynienia z błędnym kołem potrzeb i pragnień, gdyż nowe potrzeby potrzebują nowych towarów, z kolei nowe towary potrzebują nowych potrzeb i pragnień. W takiej rzeczywistości dobra materialne, towary, starzeją się w sposób przyspieszony, co wymaga natychmiastowego ich pozbywania się i zastępowania przedmiotami nowszymi. Wiele cenionych rzeczy szybko traci powab, blask, „może się okazać, że nim posiadacz miał szansę się nimi nacieszyć, nadają się jedynie na wysypisko śmieci” (Bauman, 2009: 39). Zygmunt Bauman dodaje:

jednym z najistotniejszych skutków utożsamiania szczęścia z nabywaniem obdarzających szczęściem towarów jest odkładanie nadziei na to, że pogoń za szczęściem kiedyś się zakończy (...) przesuwając chytrze marzenia o szczęściu z wizji pełnego i w pełni satysfakcjonującego życia na tropienie środków niezbędnych jakoby do jego osiągnięcia, rynki dbają o to, aby poszukiwania nigdy nie dobiegły końca. Obiekty tropienia zmieniają się z zawrotną prędkością. Zarówno sami tropiciele, jak i ich gorliwi mentorzy tudzież przewodnicy zdają sobie sprawę, że jeśli poszukiwania mają przynieść zamierzony skutek, poszukiwane przedmioty muszą szybko wychodzić z użycia, tracić połysk, powab i moc uwodzenia. Trzeba umieć rozstać się z nimi bez żalu, gdy przyjdzie je zastępować innymi,

${ }^{1}$ B. Matyjas (2008: 40) pisze o „dzieciństwie nadmiaru”, w niniejszym opracowaniu będę starała się zaakcentować kwestię obfitości, a nie nadmiaru. 
„nowszymi i jeszcze lepszymi” produktami, z góry na podobny los skazanymi. Szczęście w postaci antycypowanego stanu błogości, mającego nastać po dokonaniu zakupu, zostaje niepostrzeżenie zastąpione przez poprzedzający ów stan akt nabywania, akt pełen radosnych oczekiwań, przesyconych czystą i nieskazitelną, bo jeszcze nie zawiedzioną, nadzieją. (Bauman, 2008: 22-23)

W tę spiralę pogoni za szczęściem rozumianym jako obfitość włączone są dzieci. Każdego dnia w ich stronę kieruje się dziesiątki reklam produktów niezbędnych, czy wręcz koniecznych do szczęścia. Wykrzywiają one obraz szczęśliwego dzieciństwa poprzez budowanie świata funkcjonującego „na zasadzie zamkniętego obiegu", w którym prezentowane są gry, reklamy produktów, a nagrodami są medialne artefakty, które stają się synonimami szczęścia rozumianego jako posiadanie kolejnych dóbr. Mariusz Jędrzejko i Karolina Karolczak-Wawrzała dostrzegają, że różnorodność ofert kierowanych w stronę dzieci sprawia, że „bycie gdzieś, zobaczenie kogoś, uczestniczenie w czymś, posiadanie czegoś staje się nie tylko potrzebą wewnętrzną, ale jest również wynikiem presji zewnętrznej" (Jędrzejko, Karolczak-Wawrzała, 2015: 107). Dzieci zachęcane, czy wręcz przymuszane do pogoni za posiadaniem kolejnych produktów, uczestniczeniem $\mathrm{w}$ określonych sposobach konsumpcji podsuwanych im w coraz atrakcyjniejszej formie, stają się członkami społeczności nazwanej przez Zygmunta Baumana rojem. Rojów nie obciąża troska o przetrwanie, obrzędy charakterystyczne dla grup, gdyż roje schodzą się, rozchodzą i ponownie zbierają z powodu różnych okazji, powodowane zawsze zmiennymi zainteresowaniami, przyciągane przez coraz to nowe, $\mathrm{z}$ reguły ruchome cele. Takim celem jest posiadanie przez dzieci kolejnej, nowej zabawki, przedmiotu, który wkrótce zastąpiony zostanie nowym, atrakcyjniejszym. Dzieci tworzą wokół niej rój, którego jedynym celem jest pokazanie, że się ma. Nie budują one zespołu skoncentrowanego na wspólnym realizowaniu określonego celu, lecz są, jak to określił Z. Bauman, „sumą części, czy zbiorem samonapędzających się elementów złożonych przez «solidarność mechaniczną» wyrażającą się w powielaniu tych samych wzorów zachowania [każde dziecko bawi się swoją zabawką tak, jak zaproponowano mu w filmie czy spocie reklamowym - dop. K.K.]. Rój przypomina ciąg powielanych obrazów Warhola, w których żaden nie jest oryginałem" (Bauman, 2009: 85). Co gorsze, każde dziecko pragnie w tym roju się znaleźć, gdyż daje on chwilowe złudzenie przynależności. W przeciwieństwie do grup, „roje nie znają odszczepieńców, czy buntowników - co najwyżej trafiają się w nich „dezerterzy”, „niedołęgi i „zabłąkane owieczki” (Bauman, 2009: 85), które pozostają poza nim, narażone na frustrację, zagubienie, poczucie niespełnienia, a więc doświadczają braku poczucia szczęścia. 


\section{Dzieciństwo aktywne}

Jonathan Haidit zauważa, że współczesny człowiek nieustannie stawia przed sobą kolejne zadania, mierzy się z wyzwaniami zewnętrznymi, które w konsekwencji mają uczynić go szczęśliwym. Wspomniany autor rozwija tę myśl następująco:

marzymy o awansie, o dostaniu się do prestiżowej szkoły, albo o pomyślnym zakończeniu dużego przedsięwzięcia. Pracujemy bez wytchnienia, wyobrażając sobie, jacy bylibyśmy szczęśliwi, gdybyśmy zdołali osiągnąć ów cel. Później go osiągamy i - jeśli mamy dużo szczęścia - doznajemy euforii, która trwa godzinę albo (w najlepszym razie) kilkanaście godzin, zwłaszcza jeśli sukces przyszedł niespodziewanie i jeżeli dowiedzieliśmy się o nim w jednej chwili. Jednak w większości przypadków wcale nie doświadczamy euforii. Kiedy sukces wydaje się coraz bardziej prawdopodobny, a wieńczące go wydarzenie tylko potwierdza to, czego zaczęliśmy się już spodziewać, doznajemy uczucia ulgi - przyjemności związanej z wywiązaniem się z podjętego zadania. W takich okolicznościach nasza pierwsza myśl rzadko brzmi „Hura! Fantastycznie!”, a dużo częściej: „W porządku. Jakie jest moje kolejne zadanie?”. (Haidit, 2007: 152)

W tym spostrzeżeniu wybrzmiewa przekonanie, że trudno współczesnemu człowiekowi odczuwać radość z tego, co wokół niego się dzieje, czego doświadcza w danym momencie życia, gdyż coś nieustannie popycha go do przodu. To pragnienie, by zyskać więcej, lepiej, szybciej, by w pośpiechu z wysiłkiem zdobywać kolejne, ulotne cele. Intensywna aktywność jest typowa dla modelu dzieciństwa „najlepszej jakości”2. W tym modelu dominuje przekonanie, że dzieciństwo, w które się inwestuje, intensywnie przeżywa, jest szczęśliwsze. Dzień, tydzień, miesiąc, rok szkolny dziecka są szczelnie wypełnione skrupulatnie zaplanowanymi aktywnościami. Nie ma czasu ani miejsca na zatrzymanie się i nudę, dzieci wychowują się „W kulturowej matrycy ciągłego szukania, sprawdzania własnych talentów i zainteresowań”. Barbara Smolińska-Theiss zauważa, że „tradycyjna kategoria «czas wolny» nie oddaje złożoności całego zjawiska związanego z planami i działaniami edukacyjnymi (...)" (Smolińska-Theiss, 2014: 245). Jest ich wiele, szczelnie wypełniają dzień wielu dzieci. Każda chwila braku aktywności wywołuje poczucie dyskomfortu u dziecka i jego najbliższych, a w konsekwencji wymyślanie i kreowanie kolejnych aktywności Życie współczesnego człowieka zdominowała przecież kategoria „czasu optymalnie wykorzystanego”. Zdaniem Sue Palmer oznacza ona wytwarzane przypadkowo godziny spędzane z dzieckiem, podczas których zarówno dziecko, jak i dorosły ma obowiązek być w dobrym nastroju (Palmer, 2007: 53).

2 Wątek dzieciństwa wysokiej jakości rozwija m.in. B. Smolińska-Theiss, 2014: 223 i dalsze, w niniejszym artykule nie będę tej kwestii szerzej podejmować. 
Jednak ich nadmiar, podobnie jak nadmiar obowiązków i zadań, wywołuje przemęczenie i poczucie braku wolnego czasu, którego doświadczają zarówno dzieci, jak i ich rodzice. Nie daje szczęścia, natomiast „pęd do osiągnięć, nieustannego działania, wyścig z czasem, odbiera dziecku jego dzieciństwo, które raz utracone nigdy nie powróci” (Cytowska, 2009: 154).

\section{Dzieciństwo w świetle reflektorów}

Obecnie popularny i często bezkrytycznie realizowany jest model dzieciństwa $\mathrm{w}$ świetle reflektorów, a obecność dziecka w mediach utożsamiana jest $\mathrm{z}$ jego sukcesem i szczęściem. W przekonaniu wielu rodziców poprzez uczestnictwo w mediach „dotyka” ono lepszego świata, ma okazję poznać ludzi popularnych i wpływowych. Faktycznie jednak podczas udziału w popularnych programach telewizyjnych dziecko sytuowane jest w roli błazna, które ma rozśmieszyć, rozbawić zgromadzonych wokół niego zdziecinniałych, niedojrzałych dorosłych. Obsadzone zostaje w roli „wdzięcznego stworzonka”, „słodkiej pociechy, słodziaka, pączusia do zjedzenia” (Cackowska, 2013: 22), słodkiego elfa - „wrażliwego i nieodpornego na realia, nieporadnego i w tej nieporadności zabawnego, rozczulającego" (Klus-Stańska: 2010: 96). Dorośli w jego otoczeniu to ludzie troskliwie pielęgnujący własną „wieczną młodość”, w rzeczywistości infantylni, zagubieni w kulturze prefiguratywnej. Kreują się na wiecznie młodych błaznów i wszechwiedzących ekspertów wypowiadających się na każdy możliwy temat. Większość z nich, jak podkreśla S. Palmer, „zdobyła rozgłos i bogactwo głównie dzięki byciu ekscentrycznym i egocentrycznym" (Palmer, 2007: 154). W swoich eksperckich rolach w mało wyszukany, często wręcz prymitywny sposób zachęcają dzieci do rywalizacji i wyścigu o jak najlepsze miejsca w kolejnych odsłonach show. Dziecko ma dobrze wpisać się w oczekiwania dorosłych, pragnących niewyszukanej rozrywki. Jego zadaniem jest odegrać rolę zgodnie z zapisem w scenariuszu. Zaś jego zachowanie, wypowiedź niezgodna z oczekiwaniami dorosłej publiczności wywołuje na twarzach zgromadzonych grymas niezadowolenia i nieprzyjazne, dezorientujące dziecko komentarze, co obrazuje następujący dialog:

Prowadzący: Co to jest łapówka?

Dziewczynka: To jest instrument?

Prowadzący: Ale jaki? Taki bardziej finansowy czy muzyczny?

Dziewczynka: Muzyczny. 
Brak reakcji publiczności i jury. Prowadzący szybko przechodzi do kolejnego pytania $^{3}$. W przytoczonym przykładzie dziecko zachowało się niezgodnie z oczekiwaniem, jego wypowiedź nie odpowiada konwencji rozbawiania dorosłych poprzez obnażanie przez dzieci „ukrytych stron” świata dorosłych. Dziecko miało być zabawne, a jego wypowiedzi powinny postawić dorosłych: rodziców (opiekunów) w sytuacjach dwuznacznych moralnie, obnażyć rodzinne tajemnice, wówczas dorosła publiczność miałaby powody do satysfakcji, a dziecięcy bohater programu zostałby nagrodzony brawami i pozytywnymi komentarzami, na przykład:

Dziewczynka: Przekleństwo, to jest takie coś, że jak mama się zdenerwuje, to przeklina. Jurorzy: Brawo!

Jedna z jurorek: Nareszcie coś z życia wzięte! ${ }^{4}$

Sytuacje dziejące się w świetle reflektorów stymulują też antagonistyczne relacje między dziećmi i motywują, by podążać do celu na skróty, w sposób niejednoznaczny moralnie. Obserwując te widowiska, nie sposób nie zgodzić się z Dorotą Zawadzką, która komentuje udział dzieci w jednym z programów następującymi słowami „w Gigantach okazuje się nagle, że nie masz talentu, że ktoś, kto robi kompletnie coś różnego i w sposób obiektywnie słaby, jest jakimś cudem lepszy od ciebie. To jak rosyjska ruletka. Jak dziecko to zrozumie? To już nie zajmuje autorów programu”. Autorka bloga opisuje sytuację naruszenia poczucia godności dziecka, istotnego elementu szerzej rozumianego dobrostanu psychicznego jednostki. Heliodor Muszyński zauważył:

człowiek, wyrastając w społeczności, przyswaja sobie pewien standard poszanowania, jakim ludzie obdarzają każdego przedstawiciela własnego gatunku. Innymi słowy każda jednostka w toku życia społecznego odkrywa, że człowiekowi tylko z tej racji, że jest człowiekiem, przysługuje prawo do poszanowania jego osoby. (Muszyński, 1974: 217)

W rezultacie takich doświadczeń dzieci odkrywają coś zupełnie innego - szanowany jesteś wówczas, gdy uda ci się poniżyć, upokorzyć konkurenta, gdy powiesz lub zrobisz coś, co wywoła śmiech widzów. Takie sytuacje wypaczają też istotę współzawodnictwa, czyniąc z niego rywalizację pozbawioną zasad. Chodzi przecież, by wygrać za wszelką cenę.

\footnotetext{
3 www.maligiganci.tvn.pl, dostęp: 19.05.2016.

4 www.maligiganci.tvn.pl, dostęp: 19.05.2016.

5 www.dorotazawadzka.blogspot, dostęp: 13.05.2016.
} 


\section{Dzieciństwo nieskrępowane}

U podstaw przekonania, że warunkiem szczęśliwego dzieciństwa jest swoboda i brak ograniczeń, znajduje się założenie, że „dzieci nie są pasywnymi podmiotami struktury i procesów społecznych, ale przyczyniają się aktywnie do tworzenia i określania swojego własnego świata społecznego" (Matyjas, 2008: 22). We wspomnieniach dorosłych na temat szczęśliwego dzieciństwa pojawiają się w wypowiedziach kategorie: wolność od obowiązków i trosk, miłość najbliższych (Sławińska, 2012: 37), możliwość spędzenia czasu na swobodnej, niczym nieskrępowanej aktywności (Sławińska, 2012: 38), w dowolnym miejscu i przyjętym przez dziecko sposobie działania. Obrazy nieskrępowanego dzieciństwa odnaleźć można w znakomitych opisach swobodnych zabaw w powieściach Astrid Lingren, na przykład Dzieci z Bullerbyn czy Dzieci z ulicy Awanturników. Z tej drugiej przytoczę wybrany fragment:

Parę dni temu bawiliśmy się w piratów i Lotta nie dawała nam spokoju. Wtedy Jonas powiedział:

- A wiesz, co się robi, kiedy zostaje się piratem, Lotta?

- Stoi się na stole i podskakuje i jest się piratem - powiedziała Lotta.

- Tak, ale jest też inny sposób, o wiele lepszy - powiedział Jonas - Leży się na podłodze pod łóżkiem zupełnie cicho...

- Dlaczego? - spytała Lotta.

- Bo leży się tak i jest się piratem, i cały czas mówi się zupełnie cicho: „Więcej jedzenia, więcej jedzenia, więcej jedzenia”. Tak właśnie robią piraci - wyjaśnił Jonas.

W końcu Lotta pomyślała, że piraci naprawdę tak robią, wlazła pod swoje łóżko i zaczęła powtarzać:

- Więcej jedzenia, więcej jedzenia, więcej jedzenia.

A Jonas i ja wdrapaliśmy się na stół w pokoju dziecinnym i żeglowaliśmy po morzach, tak na niby, oczywiście.

(...)

Bawimy się także w szpital. Jonas jest doktorem, ja pielęgniarką, a Lotta chorym dzieckiem, które leży w swoim łóżeczku.

- Ja nie chcę leżeć w łóżku - powiedziała Lotta, kiedyśmy ostatnio chcieli, żeby była chorym dzieckiem.

- Chcę być doktorem i wkładać Mii łyżeczkę do gardła.

- Nie możesz być doktorem, bo nie potrafisz pisać recepty - powiedział Jonas.

- Czego nie potrafię pisać? - spytała Lotta.

- Recepty, tego, co doktor pisze. Jak trzeba leczyć chore dziecko, chyba wiesz? - odparł Jonas.

Jonas umie pisać drukowanymi literami, mimo że jeszcze nie chodzi do szkoły. Czytać też umie.

W końcu udało nam się położyć Lottę do łóżka jako chore dziecko, chociaż nie chciała. 
- No, jak się czujemy? - spytał Jonas (...)

- Muszę zrobić jej zastrzyk - powiedział Jonas. Bo kiedy raz Jonas był chory, doktor zrobił mu zastrzyk w rękę, żeby znowu był zdrowy. Dlatego teraz Jonas chciał zrobić Lotcie zastrzyk. Wziął więc igłę od cerowania, bo udawaliśmy, że to strzykawka taka, jaką mają doktorzy. Ale Lotta nie chciała żadnego zastrzyku. Wierzgała nogami i krzyczała.

- Nie wolno wam robić mi zastrzyku.

(...)

- Ale ja i tak nie chcę żadnego zastrzyku! - krzyczała Lotta. Tak więc nie mogliśmy się już bawić w szpital.

- A ja i tak wypiszę lekarstwo - powiedział Jonas. Usiadł przy stole i niebieską kredką pisał na kartce. Pisał drukowanymi literami, ale ja nie umiałam tego przeczytać. Jonas i ja uważamy, że przyjemnie jest bawić się w szpital (...). (Lindgren, 2015: 13-22)

Dziecięca zabawa według Astrid Lingren to czas wypełniony wyobrażaniem sobie i kreowaniem rzeczywistości zgodnie z tym, co dziecko na temat tej rzeczywistości wie i potrafi sobie przedstawić w swoim umyśle. Wyobraziwszy sobie na przykład, że otrzymało list od tajemniczego nadawcy, który ukrył skarb na wyspie, dziecko wchodzi w rolę poszukiwacza, musi zatem postępować zgodnie $\mathrm{z}$ regułami odpowiednimi dla poszukiwania skarbu. Konieczne jest zaopatrzenie się w akcesoria niezbędne do podjęcia czynności poszukiwawczych. Muszą one spełniać kryteria pozwalające na przeprowadzenie poszukiwań. Przedmiotom i obiektom trzeba więc przypisać role i określić zasady ich wykorzystania. Czyniąc to, dziecko korzysta ze swojej wiedzy i doświadczenia. Podejmuje i realizuje zabawę tak, jak wie i potrafi. Bawiąc się, przetwarza to, co może dostrzec i zaobserwować w swoim otoczeniu wybierając te jego elementy, które pozwalają mu bawić się zgodnie z przyjętą regułą (regułami). Niestety, współczesne dzieci mają jedynie okazję do podejmowania aktywności będącej pozorem nieskrępowanej zabawy, faktycznie styl zabawy uległ diametralnej zmianie. Na pewno nie można o niej powiedzieć, że jest swobodna i nieskrępowana. Najmłodsi funkcjonują w otoczeniu przedmiotów wymyślonych dla nich przez dorosłych, przedmiotów zwanych nowoczesnymi, interaktywnymi zabawkami. Jednak w rzeczywistości wcale nie służą one do zabawy, lecz wymagają uruchomienia za pomocą przycisku. Wiele z nich podczas manipulacji podjętej przez dziecko łatwo może ulec zniszczeniu, uszkodzeniu, dziecko może zgubić jakiś ważny element. Bawiąc się, musi więc zachować ostrożność, postępować zgodnie ze wzorem-instrukcją. Nie może przejawiać własnej pomysłowości, kreatywności, nie może bawić się tak, jak chce. Może jedynie odtwarzać ruchy, sytuacje zaprojektowane przez tych, którzy wiedzą, jak dziecko przywiązać do określonej marki, czego wyrazem jest następujący opis reklamujący popularną zabawkę: 
Każdego roku kreacja świątecznej edycji Barbie zaskakuje niezwykłym krojem i perfekcją każdego szczegółu. Stylowa fryzura, wieczorowy makijaż i piękne dodatki podkreślają elegancką, pełną rozmachu świąteczną stylizację. To wielkie wydarzenie dla kolekcjonerów kultowej lalki Barbie. Od 27 lat Świąteczna Barbie pojawia się przed Bożym Narodzeniem i zachwyca kreacją (...). Tegoroczny model Świątecznej Barbie to kwintesencja świątecznych inspiracji. Rubinowo-srebrna suknia z kaskadami falban w kształcie dzwonu idealnie prezentuje się na obu dostępnych w sprzedaży modelach lalek: jasnoskórej blondynce i ciemnoskórej brunetce ${ }^{6}$.

Współczesne dziecko, zamiast biegać, poznawać okolicę wokół domu, wspinać się na drzewa i brodzić w kałużach, zostało zamknięte w pokoju i otrzymało zabawki naśladujące luksusowy, lukrowany i nieautentyczny świat (np. Barbie jako panna młoda, różowy samochód Barbie, różowa garderoba Barbie, różowe przyrządy do stylizacji, włosów, sztuczne włosy Barbie itp.). Patrząc na takie zabawki i próby bawienia się nimi podejmowane przez dzieci, nie sposób nie zgodzić się z Bronisławą Dymarą, która stwierdziła, że trzeba „wskrzesić żywioł i radość zabawy” (Dymara, 2009: 36), trzeba te pozory zabawy zastąpić autentyczną zabawą niosącą radość i doświadczenia ważne dla przyszłego życia.

\section{Dzieciństwo między ludźmi}

Wielu pedagogów i psychologów badających relacje społeczne stwierdza, że jednostkowe poczucie szczęścia wiąże się z bogatymi i różnorodnymi kontaktami społecznymi. Współczesne dziecko funkcjonuje w wielu przestrzeniach społecznych i ma sposobność nawiązać szereg relacji z innymi ludźmi w domu, przedszkolu (szkole), sąsiedztwie, sklepie, na podwórku, podczas zajęć pozalekcyjnych, w klubie sportowym. Eksponowanie indywidualizmu oraz zaspokajania jednostkowych potrzeb i aspiracji sprawia jednak, że inni ludzie postrzegani są jako konkurenci i rywale, wobec których należy zachować ostrożność, a nawet traktować nieufnie. W związku z tym większość kontaktów społecznych, które podejmuje człowiek w XXI wieku, to przelotne spotkania, podczas których najmłodsze pokolenie przyswaja między innymi zasady „uprzejmej nieuwagi”. Jak pisze Anthony Giddens, „uprzejma nieuwaga nie jest zwykłym niezwracaniem uwagi na obecność drugiego człowieka, lecz polega na tym, aby nie wykonać żadnego gestu, który mógłby być odebrany jako wtargnięcie w jej przestrzeń prywatną" (Giddens, 2010: 102). A. Giddens podkreśla dalej, że „nasze życie przebiega, opierając się na powtarza-

\footnotetext{
${ }^{6}$ www.glamour.pl, dostęp: 8.04.2016.
} 
nych z dnia na dzień, z tygodnia na tydzień, z miesiąca na miesiąc i z roku na rok podobnych wzorach zachowań" (Giddens, 2010: 102). Obserwując i naśladując najbliższych, otrzymując od nich informacje dotyczące pożądanych w danej sytuacji reakcji, uczy się być między ludźmi tak, aby nie wchodzić w relacje. Dodać należy, że większość relacji współczesnego człowieka (także dziecka) to relacje przelotne, szybkie, krótkie, to także niebezpośrednie (w Internecie, za pomocą poczty elektronicznej itp.). Większość dzieci funkcjonuje w świecie nierzeczywistych kontaktów z innymi ludźmi, a ich przedstawicielem jest pewien dziewięciolatek opisany przez S. Palmer, który podczas rozmowy „z dumą zaprezentował swój «wirtualny świat» - sypialnia, w której był telewizor, odtwarzacz DVD, komputer, konsola do gier (...). Tu właśnie spędzał większość czasu po lekcjach” (Palmer, 2007: 131). Na pytanie, gdzie w tym czasie są twoi rodzice, kiedy ty przebywasz w świecie wirtualnym, autorka usłyszała następującą odpowiedź: „Tata ogląda mecze w telewizji, a mama... mama chyba sprawdza e-maile” (Palmer, 2007: 131). Multimedia miały ułatwić i usprawnić kontakty i komunikację między ludźmi, tymczasem badania pokazują wyraźnie, że dzieci, które mają nieskrępowany dostęp do telewizji, komputera i telefonu komórkowego, które przejawiają dużą aktywność w wirtualnych sieciach społecznościowych, mniej czasu spędzają, nawiązując bezpośrednie relacje społeczne $\mathrm{z}$ rówieśnikami, a to z kolei odzwierciedla się w poczuciu braku szczęścia i wyobcowania (Pinker, 2015: 228-231). A przecież nie od dziś wiadomo, że relacje $\mathrm{z}$ innymi ludźmi zachodzące w czasie rzeczywistym i twarzą w twarz mają kluczowe znaczenie dla jednostkowego poczucia szczęścia. S. Pinker podkreśla na przykład, że „wytworzone przez nas więzi społeczne determinują nasz poziom zadowolenia z życia, zdolności poznawcze oraz odporność na infekcje i choroby przewlekłe" (Pinker, 2015: 23).

\section{Podsumowanie}

Podsumowując swoje rozważania, przywołam słowa Zygmunta Baumana, który, opisując otaczający nas świat i funkcjonujących w nim ludzi, zauważył, iż

można obsypywać bliskich drogimi prezentami, żeby wynagrodzić ich za czas, który można było spędzić z nimi, a którego się z nimi nie spędziło, za wszystkie nieodbyte rozmowy i za całkowity lub niemal całkowity brak bardziej przekonujących oznak naszego zainteresowania, współczucia, troski. Lecz ani znakomity smak restauracyjnych potraw, ani markowe metki z wysokimi cenami przyczepione do zakupionych w sklepie prezentów nie dorównują wartością szczęściu, jakie przynieść mogłyby te dobra, których brak lub niedobór chce się w ten sposób zrekompensować. Nic nie zastąpi wspólnej obecności przy 
stole, zastawionym potrawami przyrządzonymi wspólnie z myślą o wspólnym ich spożyciu, nic nie zastąpi czasu, który ktoś dla nas ważny poświęci na cierpliwe, uważne słuchanie naszych najbardziej intymnych przemyśleń, nadziei, obaw, nic nie zastąpi autentycznych dowodów przepełnionej miłością uwagi, oddania i troski. Ponieważ nie wszystkie dobra konieczne dla osiągniecia „subiektywnego poczucia szczęścia” da się sprowadzić do wspólnego mianownika (a dotyczy to zwłaszcza dóbr materialnych), wymykają się one próbom ilościowego zbilansowania. (Bauman, 2008: 18)

Zamiast gonić za szczęściem i tworzyć dzieciom pozory szczęśliwego dzieciństwa, może lepiej po prostu wtedy, gdy to jest możliwe, zwolnić tempo życia i pielęgnować chwile, które trwają, bo przecież „dzielenie się radością życia jest istotą satysfakcjonującej relacji dziecka z rodzicem” (Siegel, 2015: 20). Może w tym kontekście warto zastanowić się nad rolą nauczyciela - osoby wspierającej rodzica w jego rodzicielskiej roli. Może czas, by nauczyciel zrezygnował z funkcji strażnika rozliczającego dziecko i jego najbliższych z realizacji kolejnych zadań szkolnych, „nakręcającego” spiralę pogoni za sukcesem mierzonym wynikami testów i rankingów i zbliżył się do dziecka i jego rodziców, by wspólnie przeżywali ważne i mniej istotne, niepowtarzalne przecież chwile.

\section{Literatura}

Adamski F. (1999). Dziecko w zmieniającej się kulturze i systemie wartości. [W:] B. Smolińska-Theiss (red.). Pokój z dziećmi. Warszawa.

Averill J.R., More T.A. (2005). Szczęście. [W:] M. Lewis, J.M. Haviland-Jones (red.). Psychologia emocji. Gdańsk.

Bauman Z. (2008). Sztuka życia. Kraków.

Bauman Z. (2009). Konsumowanie życia. Kraków.

Bogunia-Borowska M. (2008). Codzienność życia społecznego - wyzwania dla socjologii XXI wieku.

[W:] P. Sztompka, M. Bogunia-Borowska (red.). Socjologia codzienności. Kraków.

Cackowska M. (2013). Ideologie dzieciństwa a/i tabu w książkach obrazkowych dla dzieci. „Opuscula Soiologica" nr 3 .

Cytowska A. (2009). Współczesne dzieciństwo w narracji terapeutycznej kultury (po)nowoczesnej.

[W:] J. Izdebska J. Szymanowska (red.). Dziecko w zmieniającej się przestrzeni życia. Obrazy dzieciństwa. Białystok.

Czapiński J. (1994). Psychologia szczęścia. Warszawa.

Dymara B. (2009). Żywioł i radość zabawy, czyli o zagubionych wartościach ludycznej edukacji. [W:] B. Dymara (red.). Dziecko w świecie zabawy. O kulturze, cechach i wartościach ludycznej edukacji. Kraków.

Frank R. (1999). Luxury Fever. Why Money Fails to Satisfy in an Era of Exess. New York.

Gajda J. (2009). Poznawanie dziecka z perspektywy współczesnej pedagogiki kultury. [W:] J. Izdebska, J. Szymanowska (red.). Dziecko w zmieniajacej się przestrzeni życia. Białystok. 
Giddens A. (2010). Socjologia. Warszawa.

Gombik Cz. (1982). Oblicza szczęścia. Warszawa.

Górnikiewicz J.Z. (2010). Edukacja w świecie zdziecinniałych dorosłych i wybujałych $w$ dorosłość dzieci. [W:] E. Jaszczyszyn, J. Szada-Borzyszkowska (red.). Edukacja dziecka. Mity i fakty. Białystok.

Haidit J. (2007). Szczęście. Od mądrości starożytnych po koncepcje wspótczesne. Gdańsk.

Humboldt W. (2012). O myśli i mowie. Warszawa.

Izdebska H. (1988). Szczęście dziecka. Warszawa.

Jędrzejko M., Karolczak-Wawrzała E. (20115). „Zawirowany” świat - w poszukiwaniu źródeł zachowań ryzykownych. [W:] U. Dudziak (red.). The Child Problems and Needs. Lublin.

Klus-Stańska D. (2010) Między wiedzą a indoktrynacją, między wychowaniem a manipulacją. „Problemy Wczesnej Edukacji” nr 1/2.

Lindgren A. (2015). Dzieci z ulicy Awanturników. Warszawa.

Łukaszewski W. (1996). Człowiek i kultura. [W:] T. Jaworska, R. Leppert (red.). Wprowadzenie do pedagogiki wyborów tekstów. Kraków.

Maciejewska-Mroczek E. (2012). Mrówcza zabawa. Wspótczesne zabawki a społeczne konstruowanie dzieciństwa. Kraków.

Matjas B. (2008). Dzieciństwo w kryzysie. Etiologia zjawiska. Warszawa.

Muszyński H. (1974). Ideał i cele wychowania. Warszawa.

Palmer S. (2007). Detoksykacja dzieciństwa. Co powinni wiedzieć rodzice, aby wychować zdrowe, dobrze radzace sobie $w$ życiu dzieci. Wrocław.

Pinker S. (2015). Efekt wioski. Jak kontakty twarza w twarz mogq uczynić nas zdrowszymi, szczęśliwszymi i mądrzejszymi. Kielce.

Postman N. (1982). The Disappearance of Childchood. New York.

Siegel D., J., Hartzell M. (2015). Świadome rodzicielstwo. Podkowa Leśna.

Sławińska M. (2012). Dzieciństwo w refleksji dorosłych-rekonstrukcja fenomenograficzna. [W:] M. Kowalik-Olubińska (red.). Dzieciństwo i wczesna edukacja w dynamicznie zmieniającym sięśsiecie. Toruń.

Smolińska-Theiss B. (2014). Dzieciństwo jako status społeczny. Warszawa.

Szyszkowska M. (1985). Zdrowie psychiczne a przeżycia radości i szczęścia. [W:] K. Dąbrowski (red.). Zdrowie psychiczne. Warszawa.

Tatarkiewicz W. (1947). O szczęściu. Kraków.

Tatarkiewicz W. (1992). Pisma z etyki i teorii szczęścia. Wrocław.

Waloszek D. (2006). Pedagogika przedszkolna metamorfoza statusu i przedmiotu badań. Kraków. 